\title{
Analisis Penilaian Afektif Pembelajaran Daring Menggunakan Learning Management System (LMS) pada Mata Pelajaran Matematika
}

\author{
Nur'aini Muhassanah ${ }^{1}$, Dwiani Listya Kartika \\ ${ }^{1}$ Universitas Nahdlatul Ulama Purwokerto \\ ${ }^{1}$ nuraini.muhassanah8790@gmail.com
}

\begin{tabular}{l}
\hline \hline Article Info \\
\hline Article history: \\
Received Aug $8^{\text {th }}, 2021$ \\
Revised Sept $20^{\text {th }}, 2021$ \\
Accepted Oct $05^{\text {th }}, 2021$ \\
\hline
\end{tabular}

Keywords:

Online Learning;

Affective Assessmen;

Learning Management

System (LMS)

\section{Kata Kunci:}

Pembelajaran Daring;

Penilaian Afektif;

Learning Management System (LMS)
The purpose of this study was to describe affective assessment in mathematics subjects using LMS media as a media to support learning activities between students and teachers in online learning. The subjects of this study were 214 students who were divided into five classes in class XI IPA SMA Negeri 1 Purbalingga. This research was conducted in July - September 2021. The data in this study were obtained from the results of filling out questionnaires related to affective assessment in online learning. The scale used to measure the affective aspect of the activities of an object is the Likert scale. The data analysis technique used descriptive statistical methods. The results showed that the implementation of the affective domain assessment in online learning through the Learning Management System (LMS) in the mathematics subjects of class XI science students at SMA Negeri 1 Purbalingga was running well. Teachers and students can already use the application as expected so that students can follow the learning well. With the LMS, it is easier for students to understand the material, get assignments and assessments and can interact and discuss with the teacher smoothly. In addition, students also remain highly motivated even though learning cannot be done face-to-face.

Abstrak
Tujuan dari penelitian ini adalah untuk mendeskripsikan
penilaian afektif pada mata pelajaran matematika dengan
menggunakan media LMS sebagai media penunjang
kegiatan belajar antara siswa dan guru pada
pembelajaran daring. Subjek penelitian ini adalah 214
siswa yang terbagi dalam lima kelas pada kelas XI IPA


SMA Negeri 1 Purbalingga. Penelitian ini dilakukan pada bulan Juli - September 2021. Data pada penelitian ini diperoleh dari hasil pengisian kuisioner terkait penilaian afektif pada pembelajaran daring. Skala yang digunakan untuk mengukur aspek afektif terhadap kegiatan suatu objek diantaranya adalah skala Likert. Teknik analisis data menggunakan metode statistik deskriptif. Hasil penelitian menunjukkan pelaksanaan penilaian ranah afektif pada pembelajaran daring melalui Learning Management System (LMS) pada mata pelajaran matematika siswa kelas XI IPA SMA Negeri 1 Purbalingga sudah berjalan baik. Guru dan siswa sudah dapat menggunakan aplikasi sesuai dengan yang diharapkan sehingga siswa dapat mengikuti pembelajaran dengan baik. Dengan LMS tersebut siswa lebih mudah memahami materi, mendapatkan tugas dan penilaian serta dapat berinteraksi dan berdiskusi dengan guru dengan lancar. Selain itu, siswa juga tetap mempunyai motivasi yang tinggi meskipun pembelajaran belum bisa dilakukan secara tatap muka.

\section{PENDAHULUAN}

Sudah hampir dua tahun dunia sedang diguncang dengan adanya virus corona atau yang sekarang disebut dengan Corona Virus Desease (Covid-19). Disebutkan bahwa virus ini pertama kali berasal dari kota Wuhan, China sejak Desember 2019 (Lee, 2020). Dengan adanya bencana wabah Covid-19 ini pemerintah Indonesia menanamkan kebijakan untuk menyikapi permasalahan ini dengan memberlakuan social distancing kepada seluruh lapisan masyarakat di segala sektor. Adapun kebijakan tersebut diberlakukan guna memutus mata rantai penyebaran Covid-19. Hal ini ternyata berdampak pada berbagai aktivitas termasuk diantaranya aktivitas belajar mengajar. Pemerintah telah menetapkan kebijakan belajar dari rumah melalui Surat Edaran Mendikbud Nomor 36962/MPK.A/HK/2020 yang berisikan bahwa pembelajaran harus dilakukan secara daring supaya Corona Virus Desease (Covid-19) dapat dicegah penyebarannya.

Adanya kebijakan diberlakukannya pembelajaran secara daring maka model pembelajaran di pendidikan sekolah mulai melakukan 
adaptasi, diantaranya melalui sistem daring. Pembelajaran daring dilakukan sebagai pilihan strategis dalam memutus penyebaran Covid-19 di lingkungan sekolah. Jadi pembelajaran daring memungkinkan pembelajaran dilakukan tanpa bertemu fisik dan berjarak (Henderson, 2003) dengan menggunakan akses internet yang baik (Clark, R. C. \& Mayer, 2003).

Pemanfaatan sistem pembelajaran daring merupakan salah satu upaya yang bisa dilakukan untuk mengatasi permasalahan dan memudahkan siswa untuk mengakses materi pelajaran. Salah satu sistem yang diterapkan oleh SMA Negeri 1 Purbalingga adalah Learning Management System (LMS) untuk mendukung dan mengelola pembelajaran secara daring agar proses belajar dan mengajar tetap berjalan dengan baik selama pandemi Covid-19. Learning Management System (LMS) merupakan suatu sistem teknologi informasi yang dikembangkan untuk mengelola dan mendukung proses pembelajaran, mendistribusikan materi mata pelajaran, dan memungkinkan kolaborasi antara guru dan siswa. Melalui Learning Management System (LMS) siswa dapat mengakses materi pelajaran yang diberikan, melakukan diskusi dengan guru melalui forum diskusi, melalui chat, serta mengakses dan mengirim tugas yang diberikan oleh guru. Menurut Wibowo, A. T. dkk (2014) dalam penelitiannya LMS efektif meningkatkan pemahaman konsep siswa dalam proses pembelajaran.

Dalam proses pembelajaran juga terdapat aspek penilaian yang harus dilakukan guru terhadap siswanya meliputi ranah kognitif, afektif, dan psikomotor. Syamsu Yusuf (2014) mengatakan bahwa ranah afektif pada dasarnya merupakan tingkah laku yang mengandung penghayatan suatu emosi atau perasaan tertentu. Ciri-ciri hasil belajar afektif akan tampak pada peserta didik dalam berbagai tingkah laku, seperti: perhatian terhadap mata pelajaran, kedisiplinan dalam mengikuti pelajaran, motivasi yang tinggi untuk mengikuti pelajaran yang diterimanya, dan penghargaan atau rasa hormat terhadap guru. Dengan demikian, evaluasi ranah afektif ialah penilaian terhadap aspek sikap siswa untuk mengetahui sejauh mana perilaku siswa sesuai dengan tujuan pembelajaran yang diharapkan. Menurut Krathwohl dkk (2014) ranah afektif ditaksonomikan 
menjadi lebih rinci ke dalam lima jenjang yaitu: menerima atau memperhatikan, menanggapi, menilai atau menghargai, mengatur atau mengorganisasikan, dan karakterisasi dengan suatu nilai. Dengan latar belakang yang sudah dipaparkan di atas, maka penelitian ini bertujuan untuk melakukan penilaian afektif pada mata pelajaran matematika dengan menggunakan media LMS sebagai media penunjang kegiatan belajar antara siswa dan guru pada pembelajaran daring.

\section{METODE PENELITIAN}

Penelitian ini adalah penelitian deskriptif dengan pendekatan secara kuantitatif, dimana menurut Sudjana (2004) metode penelitian deskriptif dengan pendekatan secara kuantitatif digunakan apabila bertujuan untuk mendeskripsikan atau menjelaskan perisitiwa atau suatu kejadian yang terjadi pada saat sekarang dalam bentuk angka-angka yang bermakna. Tujuan dari penelitian ini adalah mendeskripsikan penilaian afektif pembelajaran daring menggunakan LMS pada mata pelajaran matematika.

Subjek dalam penelitian ini adalah siawa-siswi kelas XI IPA SMA Negeri 1 Purbalingga yang sudah mengikuti pembelajaran daring dalam mata pelajaran matematika dengan menggunakan LMS. Pengumpulan data terkait dengan penilaian afektif pembelajaran daring ini diperoleh dari instrumen dalam bentuk kuisoner berupa pertanyaan yang telah dipilih sesuai dengan penilaian afektif. Peneliti memberikan pertanyaan terbuka terhadap responden yang berjumlah 214 siswa yang mengikuti mata pelajaran matematika secara daring menggunakan LMS. Siswa dapat menjawab pertanyaan yang diberikan oleh peneliti melalui Google Form agar mudah diakses oleh siswa. Skala yang digunakan untuk mengukur aspek afektif terhadap kegiatan suatu objek diantaranya adalah skala sikap, dimana skala sikap yang sering digunakan adalah skala Likert.

Djaali dan Muljono (2008) menuliskan bahwa skala Likert adalah skala yang dapat digunakan untuk mengukur sikap, pendapat, dan persepsi seseorang atau sekelompok orang tentang suatu gejala atau fenomena pendidikan, yang biasanya termuat format skala Sangat Kurang 
Baik (SKB) sampai dengan Sangat Baik (SB). Analisis data dalam penelitian ini menggunakan statistik deskriptif. Menurut Ghozali (2011) statistik deskriptif memberikan gambaran atau deskripsi suatu data yang dilihat dari rata-rata (mean), standar deviasi, maksimum, minimum, sum, range, kurtosis, dan skewnes. Analisis data yang telah terkumpul sebagaimana adanya tanpa bermaksud membuat kesimpulan yang berlaku untuk umum atau generalisasi dengan menggunakan formula persentase.

\section{HASIL PENELITIAN DAN PEMBAHASAN}

Dengan adanya pandemi Covid-19 ini maka pelaksanaan pembelajaran dilakukan secara daring, hal ini membuat dunia pendidikan harus adaptasi dengan situasi pandemi ini dengan melakukan pembelajaran daring. Salah satu sekolah yang juga melaksanakan pembelajaran daring adalah SMA Negeri 1 Purbalingga dimana dalam pelaksanaannya menggunakan media Learning Management System (LMS), sehingga para pendidik tidak dapat berhadapan langsung dengan siswanya saat pembelajaran. Oleh sebab itu perlu dilakukan penilaian afektif oleh siswa, sehingga siswa mengetahui sejauh mana tujuan yang telah ditetapkan tercapai agar para pendidik mempunyai gambaran bagaimana pembelajaran berikutnya dapat berlangsung dengan baik.

Untuk mendapatkan data terkait dengan penilaian afektif pada pembelajaran daring dengan menggunakan LMS, peneliti memberikan kuisioner yang diisi oleh responden sejumlah 214 siswa yang berasal dari 5 kelas XI-IPA SMA Negeri 1 Purbalingga, maka dapat ditunjukkan oleh Gambar 1. berikut ini:

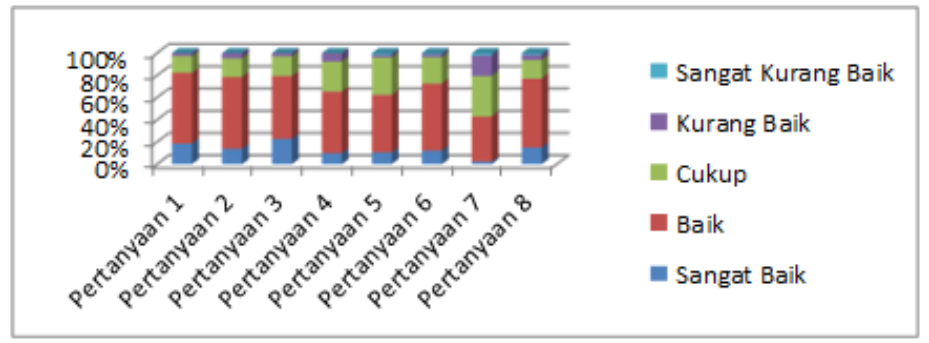

Gambar 1. Hasil Penilaian Afektif 
Selanjutnya berdasarkan hasil pengisian kuisioner terkait penilaian afektif yang diperoleh dari responden melalui Google Form diperoleh skor dominan untuk setiap pernyataan yang disajikan dalam bentuk Tabel 1. berikut ini.

Tabel 1. Persentase Jawaban Dominan Responden

\begin{tabular}{|c|c|c|c|}
\hline No & Aspek & Persentase & Kriteria \\
\hline 1 & $\begin{array}{l}\text { Bagaimana tanggapanmu saat mengikuti proses } \\
\text { pembelajaran daring melalui LMS? }\end{array}$ & $63.6 \%$ & Baik \\
\hline 2 & $\begin{array}{l}\text { Bagaimana perhatianmu ketika pembelajaran } \\
\text { daring sedang berlangsung? }\end{array}$ & $64.5 \%$ & Baik \\
\hline 3 & $\begin{array}{l}\text { Bagaimana pendapatmu terkait LMS (Learning } \\
\text { Management System) yang digunakan dalam } \\
\text { pembelajaran daring mudah untuk diakses dan } \\
\text { diikuti? }\end{array}$ & $56.5 \%$ & Baik \\
\hline 4 & $\begin{array}{l}\text { Apakah penyajian materi mudah diterima dan } \\
\text { dipahami oleh siswa ketika mengikuti } \\
\text { pembelajaran daring melalui LMS (Learning } \\
\text { Management System)? }\end{array}$ & $55.6 \%$ & Baik \\
\hline 5 & $\begin{array}{l}\text { Bagaimana pemberian tugas dan penilaian } \\
\text { yang dilakukan oleh guru kepada siswa? }\end{array}$ & $51.9 \%$ & Baik \\
\hline 6 & $\begin{array}{l}\text { Bagaimana interaksi antara guru dan siswa saat } \\
\text { pembelajaran menggunakan LMS sebagai } \\
\text { media pembelajaran? }\end{array}$ & $60.3 \%$ & Baik \\
\hline 7 & $\begin{array}{l}\text { Apakah dalam proses pembelajaran melalui } \\
\text { LMS (Learning Management System) siswa } \\
\text { lebih mudah berdiskusi? }\end{array}$ & $40.7 \%$ & Baik \\
\hline 8 & $\begin{array}{l}\text { Apakah siswa tetap memiliki motivasi untuk } \\
\text { giat belajar meski pembelajaran melalui LMS } \\
\text { (Learning Management System)? }\end{array}$ & $62.1 \%$ & Baik \\
\hline
\end{tabular}

Berdasarkan hasil data yang diperoleh dari jawaban responden terkait penilaian afektif maka bisa dilihat tingkat afektif individu pada tabel dan diagram untuk masing-masing pertanyaan yang mengacu pada tingkat kepuasan siswa pada saat pembelajaran berlangsung mata pelajaran matematika yang dilakukan melalui Learning Management 
System (LMS). Hasil dari jawaban untuk pertanyaan No 1 disajikan dalam Tabel 2. dan Gambar.2 berikut ini.

Tabel 2. Penggunaan LMS dalam Pembelajaran Daring

\begin{tabular}{cccc}
\hline No & Kriteria & Jumlah Siswa & Persentase (\%) \\
\hline 1 & Sangat Baik & 40 & 18.7 \\
\hline 2 & Baik & 132 & 63.6 \\
\hline 3 & Cukup & 32 & 15 \\
\hline 4 & Kurang Baik & 6 & 2.7 \\
\hline 5 & Sangat Kurang Baik & 0 & 0 \\
\hline
\end{tabular}

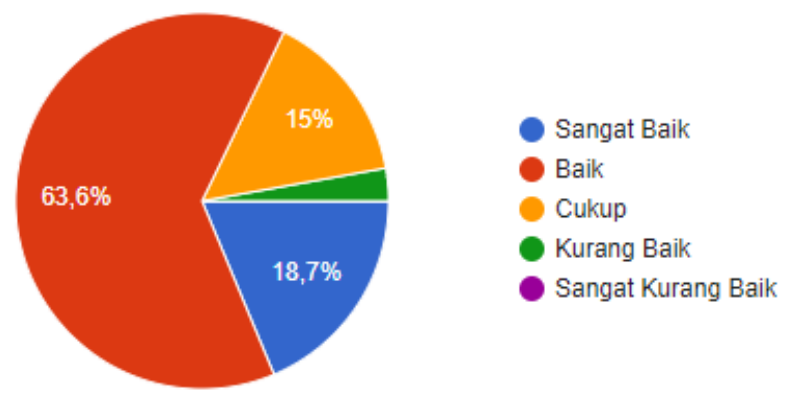

\section{Gambar 2. Penggunaan LMS dalam Pembelajaran Daring}

Berdasarkan Tabel 2. dan Gambar 2. di atas terlihat bahwa ketika pembelajaran daring berlangsung melalui LMS ada $63.6 \%$ atau sebanyak 132 siswa merespon dengan predikat baik, 40 siswa (18.7\%) merespon dengan predikat sangat baik, 32 siswa $(15 \%)$ merespon dengan predikat cukup, 6 siswa (2.7\%) dengan predikat kurang baik dan tidak ada siswa yang merespon predikat sangat kurang baik. Pertanyaan pada nomor 1 ini mengacu kepada salah satu aspek afektif yaitu bentuk receiving (penerimaan) yang meliputi kesadaran dan keinginan untuk menerima stimulus, mengontrol, dan menyeleksi gejala-gejala atau rangsangan yang datang dari luar. Salah satu aplikasi dari receiving ini adalah tanggapan siswa terhadap pembelajaran daring yang dilaksanakan melalui LMS.

Pembelajaran daring merupakan hal baru bagi peserta didik, dimana mereka harus memahami bagaimana penggunaan LMS saat pembelajaran. Selain itu juga fasilitas seperti gadget dan kuota internet juga suatu 
kebutuhan yang harus peserta didik siapkan dalam proses pembelajaran daring ini. Hal ini pasti akan mendapatkan tanggapan yang berbeda dari peserta didik dilihat dari total responden 214 siswa dan paling dominan itu adalah baik yaitu sebanyak 132 siswa (63.6\%). Baik disini berarti bahwa peserta didik memberikan tanggapan yang baik dan positif terkait dengan pembelajaran daring dengan menggunakan LMS. Kemudian ada responden sebanyak 32 siswa (15\%) untuk kategori cukup dan 6 siswa (2.7\%) untuk kategori kurang baik ini berarti waktu kelas online melalui LMS mereka kurang tanggap terkait proses pembelajaran. Selanjutnya hasil respon siswa terkait perhatian siswa pembelajaran daring dapat dilihat pada Tabel 3 dan Gambar 3 berikut ini:

Tabel 3. Perhatian Siswa Saat Pembelajaran Daring

\begin{tabular}{cccc}
\hline No & Kriteria & Jumlah Siswa & Persentase (\%) \\
\hline 1 & Sangat Baik & 30 & 14 \\
\hline 2 & Baik & 138 & 64.5 \\
\hline 3 & Cukup & 36 & 16.8 \\
\hline 4 & Kurang Baik & 10 & 4.7 \\
\hline 5 & Sangat Kurang Baik & 0 & 0 \\
\hline
\end{tabular}

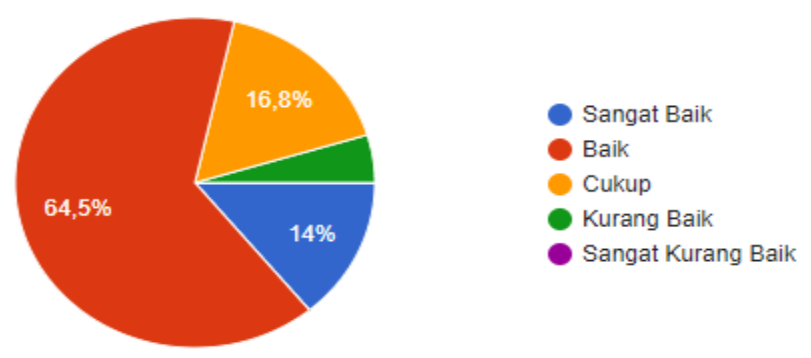

\section{Gambar 3. Perhatian Siswa Saat Pembelajaran Daring}

Berdasarkan Tabel 3 dan Gambar 3 terlihat paling banyak siswa mengisi kriteria baik untuk perhatian siswa pada pembelajaran daring menggunakan LMS sebanyak 64.5\% (138 siswa). Selanjutnya merespon cukup sebanyak $16.8 \%$ dan sangat baik sebanyak $14 \%$. Untuk predikat yang paling sedikit direspon adalah kurang baik (4.75\%) dan tidak ada yang merespon kriteria sangat kurang baik. Hal ini menunjukan sebagian besar siswa sudah memperhatikan proses pembelajaran daring dengan 
baik. Hal ini mengacu kepada salah satu aspek afektif yaitu bentuk receiving (penerimaan) yang diberi pengertian sebagai kemauan untuk memperhatikan suatu kegiatan atau suatu objek. Dalam hal ini kegiatan yang menjadi fokus adalah pembelajaran daring.

Tabel 4. Kemudahan Mengakses LMS

\begin{tabular}{cccc}
\hline No & Kriteria & Jumlah Siswa & Persentase (\%) \\
\hline 1 & Sangat Baik & 49 & 22.9 \\
\hline 2 & Baik & 121 & 56.5 \\
\hline 3 & Cukup & 38 & 17.8 \\
\hline 4 & Kurang Baik & 6 & 2.8 \\
\hline 5 & Sangat Kurang Baik & 0 & 0 \\
\hline
\end{tabular}

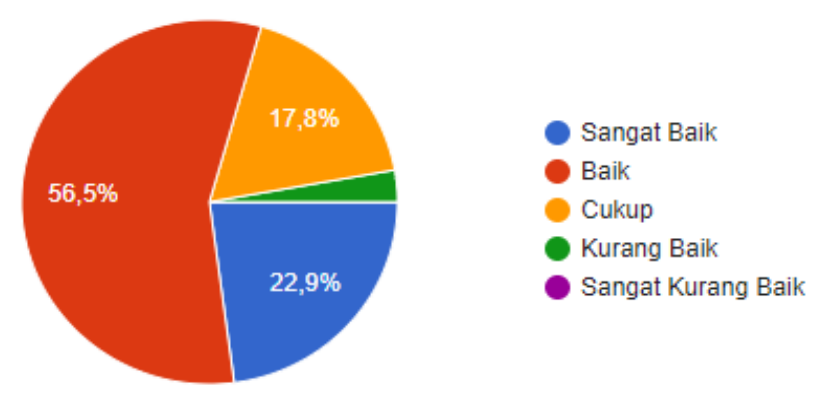

Gambar 4. Kemudahan Mengakses LMS

Berdasarkan Tabel 4 dan Gambar 4 terlihat paling banyak siswa merespon dengan kriteria baik untuk kemudahan siswa dalam mengakses LMS sebanyak 56.5\% (121 siswa). Selanjutnya 22.9\% (49 siswa) merespon sangat baik dan $17.8 \%$ (38 siswa) merespon cukup. Untuk predikat yang paling sedikit direspon adalah kurang baik (2.8\%) dan tidak ada yang merespon kriteria sangat kurang baik. Hal ini menunjukan sebagian besar siswa sudah dapat mengakses LMS sebagai media pembelajaran daring dengan mudah. Hal ini mengacu kepada salah satu aspek afektif yaitu bentuk responding (menanggapi) yang diberi pengertian peserta didik tumbuh hasratnya untuk mempelajari lebih jauh atau menggali lebih dalam lagi terkait media pembelajaran daring yang digunakan. 
Tabel 5. Penyajian Materi Melalui LMS

\begin{tabular}{cccc}
\hline No & Kriteria & Jumlah Siswa & Persentase (\%) \\
\hline 1 & Sangat Baik & 21 & 9.8 \\
\hline 2 & Baik & 119 & 55.6 \\
\hline 3 & Cukup & 58 & 27.1 \\
\hline 4 & Kurang Baik & 16 & 7.5 \\
\hline 5 & Sangat Kurang Baik & 0 & 0 \\
\hline
\end{tabular}

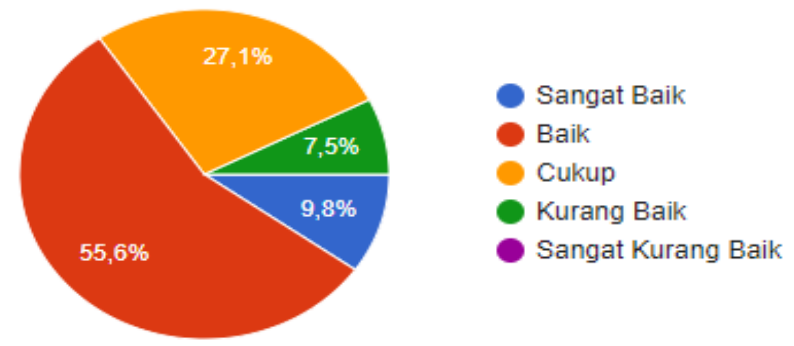

Gambar 5. Penyajian Materi Melalui LMS

Pada Tabel 5 dan Gambar 5 di atas dapat dilihat bahwa ada 21 siswa (9.8\%) responden yang menjawab sangat baik, 119 siswa (55.6\%) menjawab baik, 58 siswa (27.1\%) menjawab cukup, 16 siswa (7.5\%) menjawab kurang baik, dan tidak ada responden yang menjawab sangat kurang baik. Dari bentuk penyajian materi yang dibagikan melalui LMS sama-sama kita bisa melihat bahwa paling dominan adalah baik. Pemberian materi yang dishare sudah baik, dilihat dari segi pemaparan yang melalui video pembelajaran dan PPT materi yang memudahkan siswa untuk memahami materi yang disampaikan dan video tersebut bisa diulang kapan saja melalui LMS untuk bahan siswa-siswi belajar. Tanggapan (responding) yaitu reaksi yang diberikan oleh seseorang terhadap stimulasi yang datang dari luar, stimulasi yang didapatkan bisa berupa audio dari video pembelajaran yang berisi penjelasan materi oleh penyaji sedangkan visual berupa PPT yang bisa di download dalam LMS. Selanjutnya hasil respon siswa terkait pemberian tugas dan penilaian oleh guru pada pembelajaran daring dapat dilihat pada Tabel 6 dan Gambar 6 berikut ini: 
Tabel 6. Pemberian Tugas dan Penilaian

\begin{tabular}{cccc}
\hline No & Kriteria & Jumlah Siswa & Persentase $(\%)$ \\
\hline 1 & Sangat Baik & 23 & 10.7 \\
\hline 2 & Baik & 111 & 51.9 \\
\hline 3 & Cukup & 72 & 33.6 \\
\hline 4 & Kurang Baik & 5 & 2.4 \\
\hline 5 & Sangat Kurang Baik & 3 & 1.4 \\
\hline
\end{tabular}

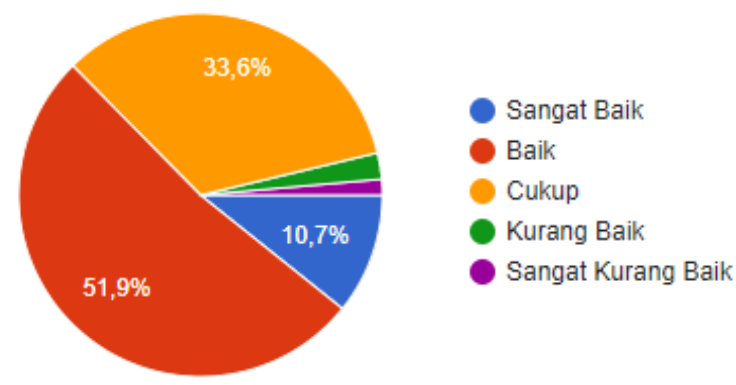

\section{Gambar 6. Pemberian Tugas dan Penilaian}

Dari data Tabel 6 dan Gambar 6 di atas terlihat bahwa pemberian tugas dan penilaian yang dilakukan oleh guru terhadap siswa dalam pembelajaran menggunakan LMS dari jumlah responden 214 siswa diantaranya ada $51.9 \%$ atau 111 siswa merespon dengan predikat baik, 72 siswa (33.6\%) merespon dengan predikat cukup, 23 siswa (10.7\%) dengan predikat sangat baik, serta hanya 5 siswa dan 3 siswa yang merespon kurang baik dan sangat kurang baik. Respon siswa untuk predikat baik sudah lebih dari separo responden mengungkapkan bahwa pemberian tugas dan penilaian yang diberikan oleh guru tidak mempersulit siswa dan relevan dengan materi yang diajarkan. Hal ini mengacu pada kepada salah satu aspek afektif yaitu bentuk menilai (valuing) dimana siswa dapat memberikan nilai atau penghargaan terhadap suatu kegiatan terkait pemberian tugas atau penilaian yang diberikan oleh guru. Selanjutnya pengisian kuisioner terkait dengan interaksi guru dan siswa pada pembelajaran daring dapat dilihat pada Tabel 7 dan Gambar 7 berikut ini: 
Tabel 7. Interaksi Guru dan Siswa saat Pembelajaran Daring

\begin{tabular}{cccc}
\hline No & Kriteria & Jumlah Siswa & Persentase (\%) \\
\hline 1 & Sangat Baik & 26 & 10.2 \\
\hline 2 & Baik & 129 & 60.3 \\
\hline 3 & Cukup & 51 & 23.8 \\
\hline 4 & Kurang Baik & 6 & 2.8 \\
\hline 5 & Sangat Kurang Baik & 2 & 0.9 \\
\hline
\end{tabular}

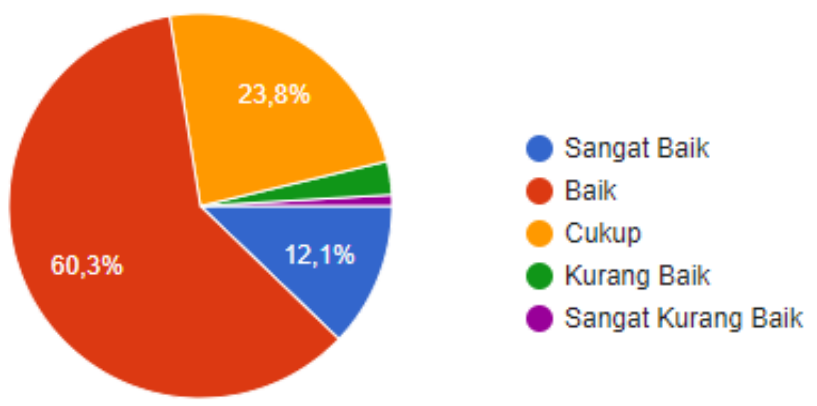

\section{Gambar 7. Interaksi Guru dan Siswa saat Pembelajaran Daring}

Berdasarkan Tabel 7 dan Gambar 7 terlihat bahwa interaksi guru dan siswa dalam saat menggunakan LMS sebagai media pembelajaran daring ada $60.3 \%$ atau sebanyak 129 siswa merespon dengan predikat baik, 51 siswa (23.8\%) merespon dengan predikat cukup, 26 siswa (10.2\%) dengan predikat sangat baik, serta 6 siswa dan 2 siswa merespon dengan predikat kurang baik dan sangat kurang baik. Jika digabungkan responden yang menjawab baik dan sangat baik hasilnya akan dominan mencapai angka $70.5 \%$ interaksi guru dan siswa berjalan dengan baik selama proses pembelajaran daring.

Tabel 8. Diskusi selama Pembelajaran Daring Melalui LMS

\begin{tabular}{cccc}
\hline No & Kriteria & Jumlah Siswa & Persentase (\%) \\
\hline 1 & Sangat Baik & 5 & 2.3 \\
\hline 2 & Baik & 87 & 40.7 \\
\hline 3 & Cukup & 78 & 36.5 \\
\hline 4 & Kurang Baik & 40 & 18.6 \\
\hline 5 & Sangat Kurang Baik & 4 & 1.9 \\
\hline
\end{tabular}




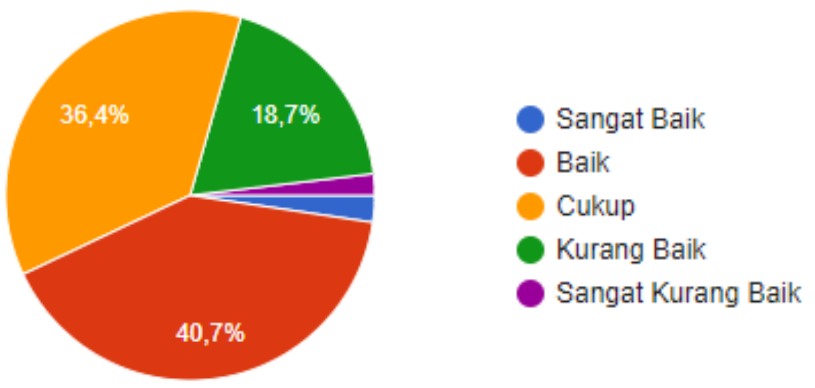

\section{Gambar 8. Diskusi selama Pembelajaran Daring Melalui LMS}

Dari data Tabel 8 dan Gambar 8 di atas terlihat bahwa kegiatan diskusi selama pembelajaran daring melalui LMS ada $40.7 \%$ atau sebanyak 87 siswa merespon dengan kriteria baik, 78 siswa (36.5\%) merespon dengan kriteria cukup, 40 siswa (18.6\%) menjawab kurang baik, 5 siswa (2.3\%) merespon dengan kriteria sangat baik, dan 4 siswa (1.9\%) merespon dengan kriteria sangat kurang baik. Jika digabungkan responden yang menjawab cukup dan kurang baik hasilnya akan dominan lebih dari separo responden sebanyak $55.1 \%$ atau sebanyak 118 siswa. Ini menunjukan diskusi selama pembelajaran daring melalui LMS kurang berjalan lancar atau baik padahal di dalam LMS sudah disiapkan forum diskusi yang bisa digunakan para siswa dan guru untuk berdiskusi, hal ini dikarenakan siswa kurang koperatif dan rajin membuka LMS untuk melakukan diskusi. Pertanyaan pada kuisioner terkait dengan motivasi siswa dalam mengikuti pembelajaran daring melalui LMS dapat dilihat hasil datanya pada Tabel 9 dan Gambar 9 berikut ini:

Tabel 9. Motivasi Siswa Mengikuti Pembelajaran Daring

\begin{tabular}{cccc}
\hline No & Kriteria & Jumlah Siswa & Persentase (\%) \\
\hline 1 & Sangat Baik & 32 & 15 \\
\hline 2 & Baik & 133 & 62.1 \\
\hline 3 & Cukup & 36 & 16.8 \\
\hline 4 & Kurang Baik & 10 & 4.7 \\
\hline 5 & Sangat Kurang Baik & 3 & 1.4 \\
\hline
\end{tabular}




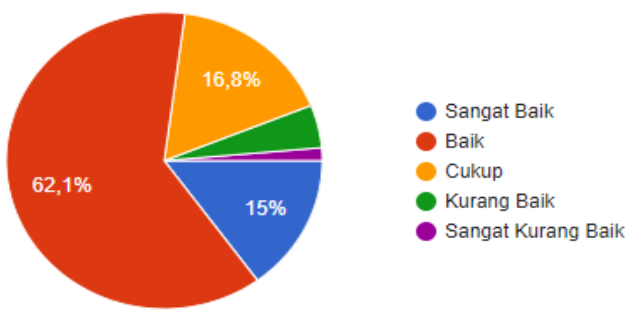

\section{Gambar 9. Motivasi Siswa Mengikuti Pembelajaran Daring}

Berdasarkan Tabel 9 dan Gambar 9 terlihat bahwa motivasi siswa dalam pembelajaran daring ada $62.1 \%$ atau sebanyak 133 siswa merespon dengan predikat baik, 36 siswa (16.8\%) merespon dengan kriteria cukup, 32 siswa (15\%) menjawab dengan kriteria sangat baik, serta 10 siswa dan 3 siswa merespon dengan kriteria kurang baik dan sangat tidak baik. Hal ini menunjukan bahwa sebagian besar siswa masih memiliki motivasi yang baik dalam mengikuti pembelajaran yang sudah disesuaikan secara daring melalui LMS. Akan tetapi, meskipun pembelajaran daring melalui LMS bisa berjalan dengan baik, proses pembelajaran tatap muka tetap masih menjadi pilihan yang paling diinginkan oleh para siswa.

Hasil penelitian ini sejalan dengan hasil penelitian Ade Rahma dkk (2020) dimana penilaian ranah afektif pembelajaran online mata kuliah IPA terpadu dikelas 5A menggunakan WhatsApp Group (WAG) sudah cukup baik. Selain itu juga menurut Ria Sudiana (2016) dalam penelitiannya dengan analisis statistic non parametric uji Kruskal Wallis diperoleh hasil bahwa semua LMS yang diujicoba memiliki efektifitas yang sama meski memiliki tingkatan kemudahan penggunaan yang berbeda-beda. Hal ini menunjukan bahwa media LMS dapat digunakan dengan mudah untuk mendukung berjalannya pembelajaran daring.

\section{SIMPULAN}

Simpulan dari penelitian ini menunjukan hasil pengisian kuisioner mengenai pelaksanaan penilaian ranah afektif pada pembelajaran daring melalui Learning Management System (LMS) pada mata pelajaran matematika siswa kelas XI IPA SMA Negeri 1 Purbalingga sudah berjalan baik. Guru dan siswa sudah dapat menggunakan aplikasi sesuai 
dengan yang diharapkan sehingga siswa dapat mengikuti pembelajaran dengan baik. Dengan LMS tersebut siswa lebih mudah memahami materi, mendapatkan tugas dan penilaian serta dapat berinteraksi dan berdiskusi dengan guru dengan lancar. Selain itu, siswa juga tetap mempunyai motivasi yang tinggi meskipun pembelajaran belum bisa dilakukan secara tatap muka. Penulis berharap hasil penelitian ini bisa menjadi refleksi terhadap proses pembelajaran daring melalui LMS untuk dapat ditingkatkan sehingga akan menghasilkan suau proses pembelajaran yang baik untuk para siswa meskipun pembelajaran tatap muka tetap menjadi yang diharapkan oleh kita semua.

\section{DAFTAR PUSTAKA}

Clark, R. C. \& Mayer, R. E. (2003). E-Learning and the Science of Instruction. Ossey-Basis/Pfeiffer.

Djaali \& Pudji Muljono. (2008). Pengukuran dalam Bidang Pendidikan. Jakarta: Grasindo.

Ghozali, Imam. (2011). Aplikasi Analisis Multivariate Dengan Program SPSS. Semarang: Badan Penerbit Universitas Diponegoro.

Gusti, Ade Rahma dkk. (2020). Penilaian Afektif Pembelajaran Daring IPA Terpadu dengan Menggunakan Media Whatsapp. DIFFRACTION: Journal for Physics Education and Applied Physics, Vol. 2 (2), 65 - 73.

Henderson. (2003). The E-Learning Question and Answer Book. American Management Association.

Krathwohl dkk. (2014). Taxonomy of Educational Objektives, Affective Domain. London: Longman Group.

Lee, J. (2020). Mental Health Effects of School Closures During Covid19. Child \& Adolescent Health.

Pusdiklat Kemdikbud. (2020). Surat Edaran Mendikbud No 4 Tahun 2020 Tentang Pelaksanaan Kebijakan Pendidikan Dalam Masa Darurat Penyebaran Corona Virus Disease (COVID-19). Pusdiklat Pegawai Kementeria Pendidikan dan Kebudayaan. 
Sudiana, Ria. (2016). Efektifitas Penggunaan Learning Management System Berbasis Online. Jurnal Penelitian dan Pengembangan Matematika (JPPM), Vol.9 (2), 201 - 209.

Sudjana, Nana. (2004). Dasar-dasar Proses Belajar Mengajar. Bandung: Sinar Baru Algensido Offset.

Wibowo, A. T., Akhlis, Isa., \& Nugroho, S. E. (2014). Pengembangan LMS Berbasis Web untuk Mengukur Pemahaman Konsep dan Karakter Siswa. Scientifik Journal Of Informatics, Vol. 1 (2), 127 137.

Yusuf, Syamsu. (2014). Psikologi Belajar Agama. Bandung: Pustaka Bani Quraish. 